\title{
Identifikasi Bakteri Coliform yang Terdapat pada Minuman Es Teh di Rumah Makan Tepi Laut Purus Padang Barat
}

\author{
Muhammad Nurman Ariefiansyah ${ }^{1}$, Netti Suharti², Eliza Anas ${ }^{3}$
}

\begin{abstract}
Abstrak
Minuman es teh merupakan minuman yang paling digemari konsumen rumah makan. Sampel penelitian ini adalah minuman es teh dirumah makan Tepi Laut Purus Padang Barat. Tujuan penelitian ini adalah menentukan kualitas minuman es teh di rumah makan Tepi Laut Purus Padang Barat secara mikrobiologis. Sampel diambil dari 14 rumah makan Tepi Laut Purus Padang Barat. Penelitian dilaksanakan dua tahap; 1. pengambilan sampel minuman es teh disertai observasi dan wawancara, 2. pemeriksaan mikrobiologis dengan metode Most Propable Number (MPN) terhadap sampel yang terdiri dari tes presumtif, tes konfirmatif dan tes pelengkap. Hasil penelitian mendapatkan seluruh sampel minuman es teh mengandung bakteri Coliform. Tiga belas dari empat belas sampel positif mengandung E. coli, sedangkan satu sampel lain mengandung bakteri Klebsiella. Dari penelitian ini dapat disimpulkan minuman es teh di rumah makan Tepi Laut Purus Padang Barat tidak memenuhi syarat mikrobiologis yang telah ditetapkan pemerintah.
\end{abstract}

Kata kunci: minuman es teh, bakteri coliform, most propable number (MPN)

\section{Abstract}

Ice tea is the common consumer favorite beverage at restaurant. Samples of this research is ice tea beverages at Purus Beach restaurant West Padang. The objective of this study was to identify the quality of ice tea sold at Purus Beach Restaurant in Purus West Padang microbiological. Samples were taken from restaurant of Purus Beach in West Padang. This research implemented in two steps; First, taking the ice tea sample and observing also interviewing. Second, microbiological inspection using Most Propable Number (MPN) methods to the sample consist of presumptive test, confirmation test and complementary test. All of the sample of the ice tea beverage containing Coliform bacteria. Thirteen of fourteen positive contained E.Coli and the other contain Clebsiella. This result showed that ice tea from Purus Beach West Padang restaurant is unqualified as government has set required microbiological.

Keywords: ice tea beverage, coliform bacteria, most propable number (MPN)

Affiliasi penulis: 1. Pendidikan Dokter FK UNAND (Fakultas Kedokteran Universitas Andalas Padang), 2. Bagian Mikrobiologi FK UNAND, 3. Bagian Biologi FK UNAND

Korespondensi: Muhammad Nurman Ariefiansyah,E-mail:

m.ariefiansyah@gmail.com, Telp: 081275426794

\section{PENDAHULUAN}

Kota Padang Terdiri dari 11 kecamatan dengan Kecamatan Padang Barat sebagai pusat kota. Pusat kota adalah lokasi yang paling strategis tempat berbagai kegiatan fungsional yang terkonsentrasi dengan intensitas tinggi, serta merupakan tempat terkonsentrasinya berbagai fasilitas pemenuhan kebutuhan penduduk yang berskala pelayanan tinggi. ${ }^{1}$
Berdasarkan data Dinas Kesehatan Kota (DKK) Padang tahun 2010, insiden diare di Puskesmas Padang Pasir yang terletak di Padang Barat menempati urutan ketiga terbanyak setelah Puskesmas Lubuk Buaya dan Puskesmas Air Dingin dengan insiden mencapai 1.032 kasus, serta merupakan jumlah terbanyak dibandingkan daerah pusat kota Padang lainnya seperti Puskesmas Alai, Padang Utara (353 kasus) dan Puskesmas Andalas, Padang Timur (331 kasus). ${ }^{2}$

Diare dapat disebabkan oleh bakteri Coliform yang terdapat dalam air, terdiri dari Escherichia coli ( $E$. coli), Kleibsiella dan sebagainya. Bakteri ini hanya 
terdapat pada kotoran manusia atau hewan, dan tidak terdapat pada air bersih. ${ }^{3}$

Berdasarkan penelitian pada tempat pengelolaan makanan diperoleh kontaminasi $E$. coli pada rumah makan di Jakarta Selatan sebesar 26,3\%, jumlah ini merupakan jumlah terbanyak dibandingkan pedagang kaki lima $(22,4 \%)$ dan jasa boga $(11,8 \%){ }^{4}$ Kontaminasi tersebut dipengaruhi oleh bahan pembuat makanan dan minuman dan kontaminasi oleh air. ${ }^{5}$ Penelitian yang dilakukan oleh Rajagukguk tahun 2008 diketahui bahwa kandungan E. coli dalam es batu di Pasar Kota Medan tidak memenuhi persyaratan air minum karena dari 10 sampel yang diuji hanya satu sampel yang tidak mengandung $\mathrm{E}$. coli. ${ }^{6}$

Minuman es teh merupakan minuman yang digemari konsumen rumah makan karena harganya terjangkau dan dapat dijadikan pendamping makanan. Minuman es teh dibuat dengan menggunakan air dan es yang merupakan salah satu sumber kontaminasi bakteri Coliform. Penelitian ini dilakukan dengan tujuan untuk mengetahui kualitas minuman es teh yang dijual di rumah makan Tepi Laut Purus Padang Barat berdasarkan persyaratan mikrobiologis yang ditetapkan oleh Peraturan Menteri Kesehatan No.492 Tahun 2010 tentang persyaratan kualitas air minum. ${ }^{7}$

\section{METODE}

Penelitian ini adalah penelitian deskriptif yang dilakukan di Laboratorium Mikrobiologi Fakultas Kedokteran Universitas Andalas Padang pada April 2012-Januari 2013. Sampel penelitian ini adalah minuman es teh yang diambil dari seluruh rumah makan yang berlokasi di Tepi Laut Purus, Padang Barat sebanyak 14 sampel. Penelitian ini dilakukan dengan mengobservasi beberapa faktor yang mempengaruhi kontaminasi bakteri Coliform pada minuman es teh di rumah makan Tepi Laut Purus Padang Barat, kemudian dilanjutkan dengan pemeriksaan mikrobiologi menggunakan metode Most Propable Number Test yang terdiri dari presumptive test menggunakan medium lactose broth, confirmative test menggunakan medium brilliant green lactose broth dan complete test menggunakan medium endo agar.

\section{HASIL}

Tabel 1. Faktor yang mempengaruhi kontaminasi bakteri Coliform pada minuman es teh di rumah makan Tepi Laut Purus Padang Barat

\begin{tabular}{lc}
\hline $\begin{array}{c}\text { Faktor-faktor yang mempengaruhi } \\
\text { kontaminasi bakteri Coliform }\end{array}$ & Persentase (\%) \\
\hline Air untuk membuat es teh & \\
a) Air galon & 14,3 \\
b) Air masak & 85,7 \\
Es yang digunakan & \\
a) Es Balok & 0 \\
b) Es Kristal & 100 \\
c) Es Batu & 0 \\
Air untuk Mencuci gelas & \\
a) Air PDAM & 93,9 \\
b) Air Sumur & 6,1 \\
Keadaan rumah makan & \\
a) Lantai & \\
1. Kayu & 35,7 \\
2. Semen & 35,7 \\
3. Keramik & 28,6 \\
b) Kebersihan & \\
1. Bersih & 78,6 \\
2. Kotor & 21,4 \\
Pembuat minuman mencuci tangan & 0 \\
\hline
\end{tabular}

Tabel diatas menunjukkan faktor-faktor yang mempengaruhi kontaminasi minuman es teh di rumah makan, yaitu: sumber air untuk membuat es teh, es yang digunakan, air untuk mencuci gelas, kondisi rumah makan dan perilaku pembuatnya.

Tabel 2. Hasil tes presumtif sampel minuman es teh

\begin{tabular}{ccc}
\hline $\begin{array}{c}\text { Tabung Tes } \\
\text { Presumtif }\end{array}$ & Sampel Positif & Persentase (\%) \\
\hline Tabung 10cc & 14 & 100 \\
Tabung 1cc & 14 & 100 \\
Tabung 0,1cc & 14 & 100 \\
\hline
\end{tabular}

Berdasarkan Tabel 2 diatas, didapatkan seluruh sampel positif pada tes presumtif dengan menunjukkan adanya produksi gas pada tabung, baik itu untuk tabung $10 \mathrm{cc}$, tabung $1 \mathrm{cc}$ dan tabung $0,1 \mathrm{cc}$. Seluruh sampel dilanjutkan tes konfirmatif. 
Tabel 3. Hasil tes konfirmatif sampel minuman es teh

\begin{tabular}{lcc}
\hline $\begin{array}{c}\text { Tabung Tes } \\
\text { Konfirmatif }\end{array}$ & $\begin{array}{c}\text { Sampel } \\
\text { Positif }\end{array}$ & Persentase (\%) \\
\hline Tabung 10cc & 2 & 14,3 \\
Tabung 1cc & 13 & 92,9 \\
Tabung 0,1cc & 13 & 92,9 \\
\hline
\end{tabular}

Tabel 3 menunjukkan bahwa pada tabung 10 cc ditemukan dua sampel positif (14,3\%) dengan adanya produksi gas pada tabung. Untuk tabung berisi $1 \mathrm{cc}$ dan $0,1 \mathrm{cc}$ sampel minuman es teh masing-masing ditemukan 13 sampel $(92,9 \%)$ positif.

Tabel 4. Hasil tes pelengkap sampel minuman es teh

\begin{tabular}{ccc}
\hline Sampel & $\begin{array}{c}\text { Koloni dengan } \\
\text { kemilau keemasan } \\
\text { dengan inti gelap }\end{array}$ & Hasil \\
\hline 1 & Ditemukan & Positif \\
2 & Ditemukan & Positif \\
3 & Ditemukan & Positif \\
4 & Ditemukan & Positif \\
5 & Ditemukan & Positif \\
6 & Ditemukan & Positif \\
7 & Ditemukan & Positif \\
8 & Ditemukan & Positif \\
9 & Ditemukan & Positif \\
10 & Ditemukan & Positif \\
11 & Ditemukan & Positif \\
12 & Ditemukan & Positif \\
13 & Tidak ditemukan & Negatif \\
14 & Ditemukan & Positif
\end{tabular}

Tabel 4 menunjukkan 13 dari 14 sampel mengandung bakteri Coliform berupa E. coli, karena ditemukan koloni dengan kilau keemasan dan satu sampel lain tidak menunjukkan pertumbuhan koloni $E$. coli. Sampel yang tidak menunjukkan pertumbuhan bakteri $E$. coli diuji dengan tes biokimia dengan menggunakan medium TSIA, medium Semi Solid, dan medium Simon's Citrat. Hasil tes biokimia menunjukkan adanya bakteri Kleibsiella dengan hasil +/+ dan terdapat gas pada medium TSIA, hasil negatif pada medium Semi solid, dan hasil positif pada medium Simon's Citrat.

\section{PEMBAHASAN}

Penelitian ini menunjukkan bahwa seluruh sampel minuman es teh rumah makan Tepi Laut Purus Padang Barat tidak memenuhi persyaratan berdasarkan PERMENKES No. 492 Tahun 2010 tentang Persyaratan Kualitas Air Minum. ${ }^{7}$ Faktor-faktor yang mempengaruhi kontaminasi bakteri Coliform pada minuman es teh adalah air yang digunakan untuk membuat es teh, es yang digunakan, air untuk mencuci gelas, keadaan rumah makan dan kebersihan pembuat minuman es teh.

Minuman es teh dibuat menggunakan air masak (85,7\%) dan air galon (14,3\%). Proses memasak air selama 2-3 menit dengan suhu $100^{\circ} \mathrm{C}$ merupakan cara sederhana untuk membunuh seluruh bakteri, kecuali spora. ${ }^{8}$ Penggunaan air masak dapat mencegah kontaminasi bakteri Coliform pada minuman es teh. Namun, pada penelitian ini ditemukan bakteri Coliform pada seluruh minuman es teh, baik yang menggunakan air masak maupun yang menggunakan air galon.

Faktor lain yang mempengaruhi kontaminasi bakteri Coliform pada minuman es teh adalah es yang digunakan. Seluruh rumah makan menggunakan es kristal untuk membuat minuman es teh. Seluruh minuman es teh yang menggunakan es kristal ditemukan adanya bakteri Coliform pada minuman tersebut.

Penggunaan air pencuci gelas adalah salah satu faktor penyebab kontaminasi bakteri pada minuman es teh. Air PDAM (93,9\%) adalah air yang banyak digunakan untuk mencuci gelas di rumah makan dibandingkan air sumur (6,1\%). Kontaminasi bakteri Coliform dapat terjadi pada air pencuci gelas karena berdasarkanpenelitian Zulfiton tahun 2010 di Pantai Purus ditemukan persediaan air bersih PDAM hanya sekitar $21,34 \%$, serta pengelolaan sampah belum memadai, pengaliran limbah masih dialirkan ke sungai, dan drainase belum teratur. ${ }^{9}$

Kebersihan rumah makan mempengaruhi kontaminasi bakteri pada minuman es teh. Sekitar 78,6\% rumah makan di Tepi Laut Purus tergolong bersih dan sisanya $(21,4 \%)$ tergolong kotor. Kebersihan rumah makan harus selalu terjaga untuk menghindari kontaminasi. Pada penelitian ini didapatkan seluruh sampel, baik yang berasal dari rumah makan bersih maupun kotor, mengandung bakteri Coliform. Hal ini memungkinkan adanya kontaminasi oleh faktor lain. Perilaku bersih pembuat minuman es teh dapat mengurangi kontaminasi 
bakteri pada minuman es teh. Salah satu perilaku bersih sederhana adalah mencuci tangan. Namun, tidak satupun pembuat minuman es teh mencuci tangan sebelum membuat minuman. Kurangnya perilaku bersih merupakan faktor penyebab kontaminasi.

Penelitian ini tidak terlalu mendalami faktorfaktor yang mempengaruhi kontaminasi bakteri Coliform pada minuman es teh. Faktor-faktor yang mempengaruhi kontaminasi didapatkan dari hasil observasi dan wawancara singkat penulis saat pengambilan sampel. Untuk itu diperlukan penelitian lebih lanjut terhadap faktor-faktor yang mempengaruhi kontaminasi bakteri Coliform pada minuman es teh.

\section{KESIMPULAN}

Minuman es teh yang dijual di rumah makan Tepi Laut Purus Padang Barat tidak memenuhi persyaratan mikrobiologis berdasarkan Peraturan Menteri Kesehatan No. 492 Tahun 2010.

\section{DAFTAR PUSTAKA}

1. Badan Pusat Statistik. Luas wilayah Kota Padang. Jakarta: BPS; 2002.

2. Dinas Kesehatan Kota Padang. Profil kesehatan tahun 2010 edisi 2011. Padang: DKK; 2011.

3. Chandra B. Pengantar kesehatan lingkungan.
Jakarta: EGC; 2007.

4. Djaja IM, Aryastami NK. Pengaruh tempat pengelolaan makanan terhadap kontaminasi makanan di Jakarta Selatan 1999-2000. Jakarta: Badan Penelitian dan Pengembangan Kesehatan Departemen Kesehatan; 2000.

5. Djaja IM. Kontaminasi E. coli pada makanan dari tiga jenis tempat pengolahan makanan (TPM) di Jakarta Selatan 2003. Makara Kesehatan. 2008;12(1):36-41.

6. Rajagukguk, Bona RR. Pemeriksaan E.coli pada es batu yang dijual di Kota Medan (skripsi). Medan: Fakultas Kesehatan Masyarakat Universitas Sumatra Utara; 2008.

7. Departemen Kesehatan RI. PERMENKES No. 492 Tahun 2010 Tentang Persyaratan Kualitas Air Minum; 2010.

8. Jawetz E, Joseph M, Edward A. Pertumbuhan, kelangsungan hidup dan kematian mikroorganisme. Dalam: Retna NE, editor (penyunting). Mikrobiologi Kedokteran. Edisi ke-23. Jakarta: EGC; 2007. hlm. 61.

9. Zulfiton $\mathrm{H}$. Konsep rusunawa untuk urban renewal bagi permukiman kumuh studi kasus kawasan pantai Purus kota Padang (tesis). Surabaya: Institut Teknologi Sepuluh Nopember; 2010. 